\title{
Pandemi dan Pemenuhan Hak Anak: Studi Kasus Peran Unicef di Yaman Pada Masa COVID-19
}

\author{
Erzalina Widya Kusuma ${ }^{1}$, Djatmiko², Resa Rasyidab ${ }^{3}$ \\ UPN Veteran Jawa Timur ${ }^{123}$
}

\begin{abstract}
The covid-19 outbreak discovered in China in December 2019 has crippled the world economy and caused the delivery of humanitarian aid to Yemen to be hampered. In addition, there are still wars that cause damage to health facilities. The battle of the Covid19 pandemic and Cholera disease add to the devastating effects on growing children in Yemen. UNICEF reports that in 2020 there were approximately 34 cases of child abuse and attacks on educational facilities involving children. This research describes the role of UNICEF in Yemen from 2019 to 2020 in fulfilling children's rights due to 3 disasters, namely Covid-19, internal conflict, and Cholera that occurred in the country. This research looks at the role of international organizations as aid providers, manifested in the form of Humanitarian Assistance. As a descriptive study, data for this research is collected from 2019 to 2020, including reports from UNICEF, the WHO website, the UN website, and various verified mass media. UNICEF's role in the form of Humanitarian Assistance in Yemen is manifested in 5 programs: education, child protection, nutrition, health, and sanitation.
\end{abstract}

Keywords: UNICEF, Yemen, Humanitarian Assistance, Covid-19 Pandemic, Children's Rights.

\begin{abstract}
ABSTRAK
Wabah Covid-19 yang ditemykan di China pada Desember 2019 telah melumpuhkan perekonomian dunia dan menyebabkan pengiriman bantuan kemanusiaan ke Yaman menjadi terhambat. Selain itu, masih terjadi peperangan yang menyebabkan kerusakan pada fasilitas Kesehatan. Perang, pandemic Covid-19, dan penyakit kolera menambah dampak buruk pada pertumbuhan anak-anak di Yaman. UNICEF, sebagai sebuah IGO yang fokus pada anak, melaporkan bahwa pada tahun 2020 ada sekitar 34 kasus kekerasan terhadap anak dan penyerangan fasilitas Pendidikan yang melibatkan anak. Penelitian ini mendeskripsikan peran UNICEF di Yaman dari tahun 2019 hingga 2020 dalam pemenuhan hak-hak anak akibat 3 bencana, yaitu Covid-19, konflik internal, dan kolera yang terjadi di negara tersebut. Penelitian ini melihat peran dari organisasi internasional sebagai penyedia bantuan yang diwujudkan dalam bentuk bantuan kemanusiaan. Sebagai studi deskriptif, data untuk penelitian ini dikumpulkan dari tahun 2019 hingga 2020, termasuk laporan dari The UNICEF, situs web WHO, situs web PBB, dan berbagai media massa terverifikasi. Peran UNICEF dalam bentuk Bantuan Kemanusiaan di Yaman diwujudkan dalam 5 program: pendidikan, perlindungan anak, gizi, Kesehatan, dan sanitasi.
\end{abstract}

Kata Kunci: UNICEF, Yaman, Bantuan Kemanusiaan, Pandemi Covid-19, Hak Anak

\section{PENDAHULUAN}

Pada tanggal 9 Maret 2020 ditetapkan sebagai pandemi global, sebab Virus Covid 19 telah menyebar di seluruh dunia (Anonim, 2020), hingga saat ini tahun 2021, negaranegara di dunia seperti Indonesia, Malaysia, Singapura, Jepang, China, Korea Selatan dan 
Lainya, sedang sibuk untuk memulihkan kesehatan dan ekonomi negara. Virus SARS-CoV2 merupakan coronavirus yang disebut pertama kali muncul di pasar binatang di Kota Wuhan, Tiongkok pada Desember 2019. Virus ini menyebabkan penyakit yang disebut Covid-19.

Ada sekitar 222 negara yang terindikasi terkena dampak dari penyebaran covid-19 (Kementerian Kesehatan Republik Indonesia, 2021) Di antaranya Indonesia, Jepang, Malaysia, Singapura, Amerika, Arab Saudi, Yaman, Pakistan, Bagian Negara Eropa dan sebagainya. Yaman adalah termasuk negara yang dinyatakan oleh Perserikatan BangsaBangsa (PBB) sebagai negara yang paling terdampak dan menimbulkan jumlah kematian tertinggi. Selain terkena dampak Covid-19 Yaman juga mengalami serangkaian masalah yang juga pelik di antaranya yaitu (Frihandy, 2014) Pertama, perang antara koalisi negara-negara yang dipimpin Arab Saudi dengan pemberontak Houthi yang terjadi sejak tahun 2004. Dampak adanya perang membuat distribusi bantuan ke Yaman menjadi terhambat. Kedua, terjadinya krisis kemanusiaan yang disebabkan karena negara Yaman dinyatakan sebagai negara termiskin di dunia versi PBB. Kurang lebih ada sekitar 24 juta orang atau $80 \%$ dari jumlah populasi di Yaman yang masih hidup bergantung pada bantuan dan kurang lebih ada sekitar 1 jutaan orang berada pada kondisi kelaparan. Ketiga, runtuhnya sistem kesehatan di Yaman, perang di Yaman menyebabkan terjadinya kerusakan sistem kesehatan di negara tersebut. Kurang lebih ada sekitar 3.500 fasilitas kesehatan di Yaman hancur akibat perang dan tersisa setengah dari jumlah tempat kesehatan di Yaman yang masih dianggap layak digunakan. Bahkan, tempat kesehatan di Yaman dilaporkan overload capacity. Keempat, jumlah kasus corona virus tidak diketahui, hal ini disebabkan tidak akuratnya perhitungan antara kelompok pemberontak dan pemerintah. Pemerintah mengumumkan pertama kali kasus yang terjadi di yaman sekitar 900 kasus, sedangkan pemberontak yang menguasai wilayah ibu kota hanya mendeteksi ada 4 kasus yang terjadi. Kelima, tenaga medis yang rentan terpapar, akibat kerusakan dan kekacauan politik menyebabkan adanya kekurangan obat dan bantuan APD untuk tenaga medis (Wirawan, 2020). Bahkan sebuah laporan dari The Economist juga menunjukkan ada sekitar 20\% dari 333 wilayah di negara itu tidak memiliki dokter, hal itu dikarenakan para dokter di sana meninggal akibat Covid-19 (Efendi, 2020).

Pandemi Covid-19 menjadi hal yang paling mengerikan bagi anak-anak karena rentan terkena penyakit ditambah dengan adanya penyakit Kolera yang diprediksi oleh Oxfam Internasional dapat meningkat pada bulan Agustus 2020 karena memasuki musim hujan (Oxfam International, 2020). Tidak hanya itu anak-anak di Yaman juga mengalami trauma mendalam akibat terjadinya perang. Dikutip dari laporan resmi UNICEF menyatakan ada sekitar 110 ribu kasus wabah Kolera antara bulan Januari hingga April tahun 2020. Kolera adalah diare akibat infeksi bakteri yang bernama Vibrio cholerae. Penyakit ini dapat terjadi pada orang dewasa maupun anak-anak dan diare yang ditimbulkan dapat parah hingga menimbulkan dehidrasi. Kolera adalah penyakit yang disebabkan oleh bakteri yang terkontaminasi dengan makanan atau minuman. Kondisi ini dapat mewabah di wilayah padat penduduk serta memiliki lingkungan yang kotor (Alodokter, 2019). Hal ini juga disampaikan oleh Sara Beysolow Nyanti perwakilan UNICEF Yaman, yang menyatakan bahwa anak-anak di Yaman terus menghadapi berbagai ancaman bagi kelangsungan hidup mereka (UNICEF, 2020d). Kemunculan penyakit Kolera disebabkan oleh tidak baiknya sanitasi air di Yaman. 
Perang telah menyebabkan masyarakat Yaman kesulitan untuk mendapatkan akses air bersih sehingga menimbulkan penyakit tersebut.

Keadaan seperti ini membuat Yaman memerlukan bantuan dari berbagai pihak salah satunya bantuan dari UNICEF sebagai organisasi yang memperjuangkan hak-hak anak (UNICEF, 2020a). Apabila masalah hak anak tidak segera ditangani dengan baik maka masalah hak anak akan berujung pada pencederaan hak-hak anak dan pelanggaran HAM yang kemudian berkaitan dengan isu keamanan manusia. Dalam pelaksanaannya UNICEF berpegang teguh dengan konvensi hak anak. Konvensi hak anak merupakan alat yang menjabarkan prinsip-prinsip tentang hak dan norma hukum untuk melindungi dan memberikan kedudukan kepada anak. PBB menyatakan bahwasanya anak-anak berhak atas perawatan dan bantuan khusus serta harus mendapatkan pengembangan kepribadian secara penuh dan harmonis. Anak-anak juga harus mendapatkan lingkungan keluarga yang aman dan nyaman (Oktadewi \& Khairiyah, 2018).

Berdasarkan latar belakang masalah yang telah dijelaskan di atas. Maka, penulis membuat rumusan masalah yakni bagaimana peranan UNICEF dalam memberikan hak anak di Yaman pada masa pandemi Covid-19 tahun 2019-2020. Untuk menjawab rumusan masalah tersebut, penulis menggunakan teori peranan organisasi internasional sebagai aid provider yang diwujudkan dalam bentuk bumanitarian assistance.

\section{KERANGKA PEMIKIRAN}

Organisasi Internasional saat ini merupakan salah satu aktor penting dalam kajian hubungan internasional. Organisasi Internasional dianggap sebagai salah satu aktor penting dalam kajian hubungan internasional karena dinilai memiliki kekuatan dalam melakukan kegiatan mediasi, menjaga perdamaian, dan memberikan bantuan kepada anggota yang membutuhkan dan berada pada kondisi darurat (Perwita \& Yani, 2005). Dalam struktur dan perannya maka organisasi internasional diharapkan mampu untuk menciptakan suatu tatanan hubungan yang kuat, karena itu kehadiran organisasi internasional dapat mencerminkan akan kebutuhan manusia untuk bekerja sama dan sekaligus menjadi alat untuk menangani masalah melalui kerja sama (Rasdiyanah, 2017). Menurut Michael Hass organisasi Internasional terbagi menjadi dua bagian yaitu (1) sebagai sebuah Lembaga atau struktur yang di dalamnya terdapat serangkaian aturan, anggota, tempat dan jadwal pertemuan; (2) organisasi internasional sebagai pengaturan untuk menjadi satu kesatuan yang utuh dan tidak terdapat aspek non-lembaga di dalamnya (Rosenau, Singer, \& Small, 1969)/ ). Oleh sebab itu, maka dapat dipahami bahwa organisasi internasional saat ini telah menjadi aktor penting dalam kajian hubungan internasional yang memiliki fungsi untuk menjadi alat dalam menangani masalah yang timbul melalui adanya kerja sama antar anggota di dalamnya. ). Oleh sebab itu, maka dapat dipahami bahwa organisasi internasional saat ini telah menjadi aktor penting dalam kajian hubungan internasional yang memiliki fungsi untuk menjadi alat dalam menangani masalah yang timbul melalui adanya kerja sama antar anggota di dalamnya.

Sehubungan dengan hal tersebut, Clive Archer menyampaikan bahwa organisasi internasional terdiri dari 3 atau lebih negara berdaulat yang memiliki kesamaan untuk mencapai sebuah tujuan dan kepentingan bersama (Archer, 2001). Setiap organisasi memiliki fungsi yang harus dijalankan oleh struktur yang kemudian apabila setiap struktur yang ada 
telah berhasil menjalankan fungsinya, organisasi internasional tersebut dapat dikatakan berhasil dalam menjalankan perannya. Menurut Kelly Kate Pease mengungkapkan bahwa IGO memiliki peranan yang berbeda-beda dalam sistem internasional yang tentunya telah disesuaikan dengan prinsip-prinsip dan sifat dasar organisasi internasional. Maka dari itu, Pease membagi peranan organisasi internasional ke dalam 5 bagian yakni problem solving, collective act, capacity building, common global market, dan aid provider (Pease, 2000). Problem solving merupakan peran organisasi internasional dengan berperan secara kolektif dalam membantu negara mengatasi suatu masalah. Collective Act Mechanism mengembangkan kemakmuran ekonomi dan kesejahteraan global.

Capacity Building adalah peran organisasi internasional dengan membantu masyarakat internasional dapat menyerap dan mengembangkan nilai-nilai serta norma sosial, seperti demokrasi, perlindungan HAM, dan keteraturan ekonomi dalam masyarakat. Common Global Market peran organisasi internasional dalam mempersatukan masyarakat internasional. Yang terakhir adalah AidProvider, peran yang dilakukan dengan menyediakan bantuan kepada victims of international politics seperti pada korban bencana alam maupun konflik atau pengungsi (Pease, 2000). Berdasarkan kelima peran yang telah dipaparkan tersebut maka dapat dipahami bahwa UNICEF dalam hal ini adalah organisasi internasional yang berperan sebagai Aid Provider dalam menangani permasalahan kekerasan anak melalui program-program bantuan yang telah direncanakan bersama. Dapat dimaknai bahwa organisasi internasional menjalankan peranan sebagai aid provider dalam situasi yang mendesak dan dalam keadaan yang membutuhkan adanya bantuan secara langsung untuk menangani masalah yang terjadi. Berhubungan dengan pelaksanaan fungsi operasional, UNICEF sebagai aid provider berperan dalam menyediakan bantuan operasional dengan membantu para pengungsi anak melalui program-program bantuan yang telah direncanakan bersama.

Waya Quiviger mendefinisikan bantuan luar negeri merupakan segala jenis bantuan yang diberikan oleh lembaga donor internasional, negara, ataupun pemerintah dan dapat berupa pinjaman maupun dalam bentuk barang atau jasa (Williams, 2006). Terdapat dua jenis kategori foreign aid menurut John W. McArthur, Humanitarian Aid yakni bantuan yang diberikan dalam keadaan darurat yang bertujuan untuk menangani krisis kemanusiaan akibat dari adanya peristiwa tertentu seperti konflik atau bencana alam. Bentuk bantuan yang diberikan dapat berupa bantuan air bersih, obat-obatan, bantuan pangan hingga fasilitas pendidikan. Kategori foreign aid yang kedua adalah Development Aid merupakan bantuan yang diberikan untuk mencapai pembangunan berkelanjutan dalam jangka panjang dalam bidang sosial, ekonomi maupun politik (McArthur \& Conway, 2012). Untuk kasus permasalahan pada kekerasan anak di Yaman pada masa pandemi Covid-19 ini Humanitarian Assistance merupakan salah satu jenis bantuan yang tepat untuk digunakan oleh UNICEF sebagai organisasi internasional. Organisasi internasional dalam menjalankan peranan sebagai Aid Provider, diwujudkan dalam bentuk Humanitarian Assistance. Menurut Heike Spieker, Humanitarian Assistance adalah sebuah tindakan memberikan bantuan dalam bentuk kemanusiaan yang bertujuan untuk meringankan penderitaan, menjamin pemenuhan hakhak manusia, hingga misi penyelamatan hidup untuk para korban yang terdampak situasi genting seperti konflik, peperangan dan bencana alam (Spieker, 2011). Melalui pemberian bantuan kemanusiaan ini diharapkan mampu meningkatkan kualitas hidup para korban 
terdampak situasi darurat tersebut. Bantuan kemanusiaan ini merupakan bantuan kemanusiaan yang bersifat jangka pendek, sehingga dapat dipahami bahwa tujuan pemberian bantuan kemanusiaan dalam keadaan darurat ini bukan untuk menyelesaikan inti permasalahan yang terjadi dan bantuan kemanusiaan ini diberikan atas dasar nilai-nilai kemanusiaan. Untuk mencegah efek domino dari situasi darurat tersebut, melalui solusi pencegahan dalam jangka pendek disebut dengan emergency relief. Emergency relief merupakan bantuan yang diberikan secara langsung dan cepat sesuai dengan prosedur yang telah ditetapkan sehingga dengan bantuan ini dapat meminimalisir timbulnya efek domino. Emergency relief meliputi berbagai bentuk bantuan yang pertama adalah material assistance yakni berupa kebutuhan dasar manusia yang dibutuhkan, seperti kebutuhan pangan, ketersediaan air bersih, ketersediaan fasilitas perawatan dan kesehatan, perlindungan hingga pemberian tempat tinggal sementara atau shelter (Australian Government, 2020). Sedangkan technical assistance merupakan bantuan yang diwujudkan ke dalam bentuk pengiriman relawan, dan tenaga ahli. Bantuan teknis ini bersifat non-material, relawan dan tenaga ahli yang dikirimkan meliputi berbagai bidang bantuan.

\section{HASIL DAN PEMBAHASAN}

\section{Hak Anak pada Masa Pandemi Covid-19}

Pada masa pandemi Covid-19 permasalahan hak anak semakin terancam, ditambah dengan beberapa permasalahan yang terjadi di Yaman. Seperti adanya konflik senjata yang merusak banyak fasilitas pendidikan, kesehatan dan tempat yang aman bagi anak-anak untuk berlindung. Akibat adanya konflik krisis air bersih juga terganggu serta bantuan covid-19 juga terhambat (BBC, 2020). Dengan keadaan seperti ini seharusnya negara dapat melindungi dan menjamin hak-hak anak tetap terpenuhi. Hal ini sesuai dengan pasal 38 Konvensi Hak Anak, bahwasanya pemerintah diwajibkan untuk memberikan perlindungan dan pemenuhan hak anak-anak dalam keadaan apa pun termasuk dalam keadaan darurat seperti yang terjadi di Yaman. Perlindungan dan pemenuhan hak anak-anak, seperti yang tercantum pada konvensi hak anak yang menjadi bagian dari perjanjian hak asasi manusia.

Sesuai yang telah tertuang pada Deklarasi Universal Hak Asasi Manusia (UDHR) sebagai dasar hukum hak asasi manusia internasional bahwa prinsip-prinsip yang melekat pada hak asasi manusia tidak dapat dicabut oleh siapa pun (SOSCN, 1948). UDHR mengandung nilai-nilai inti mengenai kesetaraan, universalitas, keadilan dan non-diskriminasi yang berlaku bagi seluruh umat manusia tanpa memandang ras, warna kulit, jenis kelamin, bahasa, agama, pandangan politik dan sebagainya, Mengacu pada UDHR, anak-anak diberikan hak tambahan yang bertujuan untuk memastikan terpenuhinya segala akses yang diperlukan dalam mendukung pertumbuhan dan perkembangan anak. Hak tambahan ini telah tercantum melalui Konvensi Hak-Hak Anak (UNCRC) yang merupakan seperangkat kewajiban dan standar yang menetapkan hak dan kebebasan bagi anak atau individu yang berusia kurang dari 18 tahun (SOSCN, 1948). UNCRC tidak dapat dinegosiasikan karena telah disepakati secara universal dan harus dipatuhi oleh seluruh pemerintah di dunia.

Dalam memberikan keamanan dan hak-hak anak agar dapat dipenuhi, pemerintah Yaman tidak dapat bergerak sendiri. Sebab adanya keterbatasan dana yang dimiliki oleh pemerintah Yaman dan banyaknya fasilitas publik yang rusak dan masih terjadinya konflik di 
saat pandemi covid-19 melanda wilayah Yaman. Oleh karena itu peran IGO sangat diperlukan dalam membantu untuk memenuhi hak-hak anak. Merujuk pada fungsi dan peranan IGO yang telah dipaparkan pada sub-bab sebelumnya, maka dapat dipahami bahwa fungsi operasional yang diimplementasikan melalui bantuan kemanusiaan yang kemudian terbagi menjadi dua yaitu bantuan material dan bantuan teknis menjadi cara yang efektif dalam menangani suatu permasalahan yang mendesak seperti terjadinya perang, konflik dan bencana alam.

Berdasarkan UNCRC yang secara detail mengatur seluruh hak-hak anak, setidaknya terdapat 5 area di mana hak-hak anak harus terpenuhi (Lawrence, Dodds, Kaplan, \& Tucci, 2019) Anak berhak atas hal berikut, antara lain: 1) kehidupan dan perkembangan pribadi, 2) kehidupan keluarga yang normal, 3) kesehatan dan kesejahteraan, 4) keamanan dan perlindungan, 5) partisipasi dalam komunitas. Kemudian pada Pasal 3 menyatakan bahwa di mana pun sistem internasional dan nasional dapat memproses hak anak yang menjadi pertimbangan utama adalah terpenuhinya seluruh hak-hak anak tersebut. Hal ini mengisyaratkan bahwa saat tidak ada lagi pihak yang menjamin kesejahteraan pengungsi anak maka IGO menjadi pihak yang berperan langsung dalam memenuhi 5 area hak-hak pengungsi anak melalui pengimplementasian peranannya.

Maka dari itu bisa disimpulkan bahwa dalam situasi darurat, pemenuhan hak-hak anak bisa dilakukan dengan memperhatikan sektor dasar seperti kebutuhan makanan dan nutrisi seimbang, pendidikan, sanitasi dan tempat tinggal yang aman. Merujuk pada bentukbentuk bantuan kemanusiaan seperti yang telah dijelaskan sebelumnya, maka dapat dipahami bahwa distribusi bantuan kepada para pengungsi anak juga terdiri dari bantuan material dan bantuan teknis. Pada bidang kesehatan mencakup pemenuhan terhadap nutrisi, gizi yang seimbang dan jaminan kesehatan. Di daerah konflik, kesehatan bayi dan anak-anak akan sangat mudah terganggu karena segala fasilitas yang tidak mendukung sehingga wabah penyakit mudah menyebar. Kecukupan nutrisi dan gizi menjadi garda terdepan dalam menangkal penyakit maka pemberian bantuan makanan bergizi menjadi salah satu yang hal penting dalam pemenuhan hak-hak anak pengungsi. Lalu, untuk menghalau dan mengobati berbagai penyakit diberikan juga bantuan-bantuan berupa obat-obatan dan imunisasi untuk bayi dan anak-anak. Di dalam menyediakan bantuan perawatan kesehatan, organisasi internasional bisa juga bekerja sama dengan berbagai lembaga kemanusiaan lain yang saling berkaitan supaya bantuan dapat diberikan dengan cepat dan tepat.

Kemudian bantuan teknis yang disalurkan oleh organisasi internasional kepada para pengungsi anak meliputi pemberian perlindungan, pelatihan dan juga penyuluhan. Dilansir dalam Save the Children perlindungan anak dalam keadaan darurat juga merupakan bentuk respons bantuan untuk pengungsi sebagai upaya mencegah dan menangani pelecehan, perpisahan keluarga, perdagangan anak, pekerja anak hingga pernikahan dini (Semmache, 2020). Perlindungan anak darurat ini telah mencakup kegiatan khusus oleh pelaku perlindungan anak. Pemberian bantuan perlindungan ini dapat diwujudkan dengan adanya pendidikan yang berkualitas dalam keadaan darurat yang merupakan hal penting untuk merespons perlindungan fisik, psikososial dan kognitif untuk anak-anak. Penyediaan bantuan pendidikan gratis dilansir dalam laman Save The Children turut membantu mengurangi dampak konflik dan bencana yang terjadi dan dapat memberikan rasa aman akan harapan masa depan. 
Tersedianya pendidikan akan membuat anak-anak lebih aman begitu juga dapat memberikan anak-anak keterampilan yang diperlukan untuk meningkatkan peluang mereka mendapatkan pekerjaan, tetap sehat dan dapat berpartisipasi dengan masyarakat (Semmache, 2020).

\section{Peran UNICEF dalam menangani pandemi Covid-19 di Yaman}

Pada masa covid-19 membuat program UNICEF sangat susah diimplementasikan sebab adanya pembatasan yang dikeluarkan otoritas lokal sejak bulan Maret 2020 yang menyebabkan bantuan menjadi terhambat (Hospita, 2020). Beberapa program pelatihan UNICEF sangat susah diimplementasikan saat pandemi Covid-19 terjadi di Yaman. Sebab Covid-19 mudah tertular melalui udara, oleh sebab itu dibutuhkan masker dan bantuan kesehatan. Namun bantuan tersebut terhambat untuk didistribusikan dengan segera karena adanya penutupan bandara yang dilakukan oleh kelompok Houthi pada 9 September 2020. Penutupan bandar ini sangat berdampak pada kedatangan 207 ton bantuan medis untuk menanggulangi pandemi Covid-19 di Yaman (Hospita, 2020). UNICEF menyediakan persediaan medis; melakukan pencegahan dengan mengembangkan fasilitas cuci tangan; mendukung adanya penyediaan akses berkelanjutan ke pelayanan perawatan kesehatan bagi perempuan, anak-anak dan komunitas yang rentan akan terserang penyakit. UNICEF memberi dukungan akses pendidikan berkelanjutan, perlindungan sosial, perlindungan anak dan layanan kekerasan berbasis gender (gender based violence). Rancangan ini dibuat atas rencana kesiapsiagaan dan respons nasional yang dipimpin oleh Organisasi Kesehatan Dunia (WHO) serta mempelajari penanganan dari negara-negara yang terdampak (UNICEF, 2020d).

Kesiagaan UNICEF terhadap wabah covid-19 sudah disiapkan sedini mungkin, mulai dari mengembankan rencana dan respons dalam menangani wabah covid-19, yang mencangkup penyediaan alat pelindung diri (APD), pencegahan dan pengendalian infeksi atau infection prevention and control (IPC) serta pengembangan penyampaian informasi mengenai wabah covid-19 (Pane, 2020). Dalam pengadaan alat pelindung diri (APD) UNICEF bekerja sama dengan The Ministry of Health $(\mathrm{MoH}) /$ Kementerian Kesehatan untuk mengatur distribusi APD dan ventilator ke sepuluh provinsi di Yaman. Dalam melatih petugas kesehatan tentang protokol covid-19 UNICEF bekerja sama dengan WHO untuk mengembangkan dan mengadopsi modul protokol kesehatan covid-19 serta memberikan sesi pelatihan kepada petugas yang rentan terinfeksi karena langsung berhadapan pasien (UNICEF, 2020h)

UNICEF juga mendukung adanya kelanjutan pelayanan imunisasi rutin yang diadakan oleh The Ministry of Population and Public Health (MoPHP) di 2.500 fasilitas kesehatan primer, 18 rumah sakit dan di tengah masyarakat yang terdampak pandemi. Sejak bulan Maret 2020 sekitar 71.365 anak dan 64.785 balita telah divaksin dengan dosis keta masing-masing Penta, Campak dan Rubella. Sekitar 48.939 wanita usia subur (15 - 49 tahun) telah divaksinasi Tetanus dan Difteri. Untuk mendukung imunisasi dan vaksin UNICEF mengirimkan 230 unit lemari Solar DirectDrive (SDD) guna menyimpan vaksin agar aman ke MoPHP. Untuk meningkatkan kapasitas penyimpanan vaksin, UNICEF mendukung pendistribusian dan pemasangan 85 SDD lainnya ke fasilitas di Al Hudaydah, Taizz, Sana'a, Amran, Dhamar, dan Al Mahwit, serta pengiriman 2.200 kotak pendingin, 8.420 pembawa vaksin, 5.200 pencatat data dan 25.000 paket es (UNICEF, 2020d)

UNICEF juga mendesak bantuan dana darurat sebesar US\$461 juta dan bantuan kesehatan untuk anak-anak di Yaman sebab mereka menghadapi kelaparan yang mematikan 
dan kekurangan bantuan saat pandemi COVID-19. Ada sekitar 30.000 anak-anak yang terancam dapat mengalami kekurangan gizi akut yang mengancam anak-anak selama enam bulan ke depan, dan jumlah keseluruhan anak-anak yang kekurangan gizi di bawah usia 5 tahun dapat meningkat menjadi 2,4 juta atau hampir setengah dari semua balita di Yaman dan terus mengalami kenaikan sekitar 20 persen. Untuk dapat memberikan keamanan dan hak-hak pada anak saat pandemi Covid-19 terjadi di Yaman. UNICEF bekerja sama dengan WHO dan pihak berwenang di seluruh Yaman untuk mendapatkan bantuan penyelamatan jiwa bagi anak-anak yang sangat membutuhkan. Bantuan tersebut antara lain mempertahankan pelayanan kesehatan umum dan program kemanusiaan untuk anak-anak di Yaman. Bekerja sama dengan berbagai pihak komunitas yang melibatkan lebih dari 16 juta orang untuk menyebarkan pesan pencegahan Covid-19 melalui media seperti TV, Radio dan Media Sosial. Memberikan pelatihan kepada 30.000 petugas kesehatan dalam pencegahan dan pengendalian infeksi dan mendistribusikan ribuan peralatan kebersihan (UNICEF, 2020a).

Pada 18 Juni 2020 UNICEF mengirimkan alat uji Covid-19 ke Yaman saat terjadi lonjakan Covid-19, guna untuk melihat respons berapa banyak penyebaran Covid-19. Gelombang pertama 10.000 tes COVID-19 tiba di Sana'a dengan pesawat sewaan UNICEF, untuk meningkatkan kapasitas pengujian COVID-19 di tengah peningkatan pesat kasus di Yaman. Pengiriman tambahan 8.000 alat tes juga telah tiba di Aden dalam beberapa hari setelahnya. Sejak kasus Covid-19 pertama secara resmi dikonfirmasi di Yaman pada 10 April, UNICEF telah mengirimkan lebih dari 33.000 respirator N95, 33.000 masker dan 18.000 Alat Pelindung Diri (APD) ke negara itu. Dalam penanggulangan Covid-19 di Yaman, UNICEF masih mengalami kekurangan dana. Sejauh ini dana yang didapat hanya sebesar 10 persen atau US\$53 juta dari dana yang dibutuhkan oleh UNICEF (UNICEF, 2020c).

\section{Peran UNICEF dalam Kesehatan dan Pemenuhan Nutrisi}

Peranan UNICEF dalam memberikan hak kesehatan pada anak-anak sangat berpengaruh terhadap kegiatan belajar dan kegiatan sehari-hari, karena kesehatan merupakan hal penting dalam hidup. Hal telah dicantumkan dalam konvensi hak anak pasal 24 dan 32 yang berbunyi "Tiap anak berbak mendapatkan standar kesehatan dan perawatan medis yang terbaik, air bersih, makanan bergiæi dan lingkungan tinggal yang bersib dan aman. Semua orang dewasa dan anakanak perlu punya akeses pada informasi kesehatan." (UNICEF, 1989). Dalam memberikan bantuan kesehatan UNICEF berfokus menangani wabah covid-19. Namun tidak lupa juga UNICEF tetap melakukan program imunisasi atau vaksinasi di masa pandemi dengan mengatur ulang jadwal yang ada agar tidak terjadi kerumunan yang dapat menimbulkan wabah covid-19. Penjadwalan ulang ini berisiko dapat membuat vaksin kadaluwarsa, sehingga UNICEF berusaha untuk dapat memberikan imunisasi dan vaksin ke seluruh masyarakat di Yaman (UNICEF, 2020g)

Pada bulan Maret 2020 Ada sekitar 323.666 anak balita yang dinyatakan mengalami malnutrisi, sekitar 19.607 anak mengalami malnutrisi akut yang menyebabkan mereka harus di rawat di rumah sakit. Dalam menangani permasalahan nutrisi UNICEF memberikan obat cacing kepada 35.022 anak. Pada tahun 2019 sekitar 129.942 anak mendapatkan micronutrient yang dapat berperan penting untuk pertumbuhan dan perkembangan anak-anak. Seperti 
kecukupan vitamin A, asam folat, yodium, zat besi dan seng. Kekurangan micronutrient dapat mempengaruhi mental dan intelligence quotient (IQ) (Rokom, 2017).

Dalam mengatasi penyakit Kolera di Yaman, Mitra UNICEF mendistribusikan obat Oral Rehydration Sachet dan Zinc ke semua gubernur. Kemudian Tidak hanya itu untuk mencegah penyebaran Kolera, UNICEF terus segera mengerahkan tim Cholera Rapid Response Teams (RRTs) setelah kasus dugaan Kolera dilaporkan. RRTs menjangkau sekitar 900.000 juta orang di 16 provinsi yang terkena wabah Kolera. Hal itu sesuai dengan teori peran organisasi internasional technical assistance yaitu bantuan yang diwujudkan ke dalam bentuk pengiriman relawan dan tenaga ahli. Kemudian upaya yang dilakukan oleh UNICEF yaitu menyampaikan pencegahan penyebaran Kolera melalui 212.980 kunjungan dari rumah ke rumah, 397 kegiatan berbasis sekolah, 3.000 kali ceramah di masjid saat Shalat Jumat, 6.456 pertemuan komunitas, 262 diskusi kelompok, 506 di pertunjukan wayang, 180 sesi di fasilitas kesehatan dan lebih dari 500 di pertemuan ibu-ibu (UNICEF, 2020b).

Untuk berkontribusi meningkatkan layanan kesehatan ibu, bayi yang baru lahir dan anak-anak di Yaman. UNICEF bekerja sama dengan UNFPA dan WHO meninjau langsung layanan tersebut yang dilaksanakan pada 16-17 Februari 2020. Pada bulan Juni UNICEF, The Ministry of Health $(\mathrm{MOH})$, WHO, UNFPA dan lembaga masyarakat di sana memberikan penyuluhan tentang kesehatan reproduksi dan Covid-19. Untuk mendukung adanya kesehatan di Yaman UNICEF membuat pelatihan untuk 178 peserta pelatihan yang dibagi menjadi 5 kategori pertama dokter kandungan, perawat ruang operasi, neonatal intensive care unit (NICU) ahli anestesi. Atas program ini ada sekitar 65\% dari 520.136 wanita yang dilaporkan hamil menerima layanan perawatan kesehatan primer (UNICEF, 2020a)

\section{Peran UNICEF dalam Education}

UNICEF dalam upaya memberikan bantuan pada sektor pendidikan bekerja sama dengan mitranya pada bidang pendidikan. Hal ini dilakukan untuk memudahkan pelaksanaan UNICEF dalam memandu negara pada saat pandemi Covid-19 berada pada tingkat kepanikan yang berbeda-beda. Maka solusi UNICEF dalam komitmennya untuk tetap memberikan layanan pendidikan pada masa pandemi agar dapat terlaksana untuk anak-anak dan sekolah-sekolah dapat kembali dibuka dan diakses dengan aman. Panduan mengenai pembukaan kembali sekolah telah dikembangkan ditingkat global berkenaan dengan langkahlangkah yang harus diambil selama dibukanya kembali layanan sekolah untuk anak-anak. Sehubungan dengan keamanan pada saat anak-anak mengakses layanan sekolah, maka perlu untuk mengutamakan perlindungan pada anak-anak. Salah satu faktor perlindungan untuk anak-anak mengutamakan tersedianya fasilitas air bersih dan sanitasi yang memadai. Kemudian tingginya tingkat penyebaran Covid-19 yang cepat maka UNICEF memberikan sosialisasi tanggap Covid-19 mencakup promosi praktik penggunaan masker, cuci tangan, dan pembatasan sosial berjarak untuk melindungi keselamatan siswa, guru, dan staf (UNICEF, 2020a)

Kondisi pandemi Covid-19 ini berdampak pada penutupan sekolah secara nasional di Yaman, mengakibatkan sebanyak 5,8 juta anak terhambat pada akses pendidikan. Secara tanggap UNICEF kemudian memfasilitasi pengembangan rencana respons Covid-19 nasional di Yaman dengan memprakarsai penilaian kebutuhan saat Covid-19. Pada tahun 
2020 terdapat sebanyak 2.000 sekolah tidak dapat digunakan untuk tujuan pengajaran. Oleh karena itu UNICEF dengan tanggap mendukung 578,647 anak dengan mendistribusikan perlengkapan belajar dan mengirimkan APD ke 4.250 pusat ujian penyelesaian ujian pada anak kelas 9 dan 12. UNICEF juga melatih sebanyak 1.200 guru di 247 sekolah mengenai protokol kesehatan agar kegiatan belajar dapat dilakukan dengan aman (UNICEF, 2020f)

Sementara itu dampak negatif dari konflik yang sedang berlangsung di Yaman juga menyebabkan masalah pada sektor pendidikan. Akibat dari permasalahan yang terjadi menyebabkan terjadinya kemunduran pada sistem pendidikan. Beberapa penyebab kemunduran sistem pendidikan tersebut pada tahun 2019 terdapat permasalahan guru yang tidak dibayar, rusaknya fasilitas pendidikan dan kurangnya sumber daya keuangan untuk mengoperasikan sekolah. Pada tahun 2019 UNICEF memberikan pelatihan kepada 6.155 guru mengenai pembelajaran aktif. Dampak dari rusaknya fasilitas pendidikan dan kurangnya sumber daya keuangan, UNICEF kemudian memberikan akses pendidikan kepada sebanyak 253.406 anak dari 31\% target yang ada (UNICEF, 2019). Hal ini diwujudkan melalui pembangunan ruang kelas semi permanen, dan rehabilitasi sekolah.

Sehubungan dengan merebaknya Covid-19 yang terjadi, UNICEF dalam menjalankan aksinya dengan memimpin pengembangan rencana respons pendidikan Covid19 di tingkat nasional dan telah disahkan oleh Kementerian Pendidikan. Rencana respons ini akan dilaksanakan pada fase yang berbeda-beda, yakni: 1) respons secara langsung dengan mengejar ketertinggalan jam sekolah termasuk penyiaran pesan pendidikan, dan peningkatan kesadaran, 2) tanggapan tentang pembukaan kembali sekolah, termasuk pembelajaran dengan metode jarak jauh sebagai alternatif dari kembalinya pembelajaran, 3)tanggapan setelah masa enam bulan, melalui peningkatan dan mempertahankan kesempatan belajar (UNICEF, 2020g). Pada bulan Mei, UNICEF bersama dengan mitranya menyelesaikan perbaikan WASH di 22 sekolah di 2 provinsi. Hal ini juga dilakukan dengan pencairan uang tunai sebagai insentif untuk guru dan staf selama minggu pertama di bulan Mei. Selama proses verifikasi dan pembayaran intensif tunai untuk mendukung guru dan staf pengajar, pesan perlindungan penanggulangan Covid-19 diberlakukan dengan tetap menjaga jarak fisik dan penyediaan handsanitizer (UNICEF, 2020e). Melalui data laporan UNICEF kluster pendidikan mengidentifikasi sebanyak 55 juta anak membutuhkan layanan pendidikan dari 78 juta anak usia sekolah di Yaman pasca terputus dari akses pendidikan pada masa Covid-19 (UNICEF, 2020f) Dengan ini kluster pendidikan menargetkan setidaknya 33 juta anak dapat kembali mengakses pendidikan, dengan peningkatan 0,5 juta anak target dari tahun 2019.

\section{Peran UNICEF dalam Child Protection}

Terlepas dari tantangan operasional yang sedang berlangsung terkait pandemi Covid19. UNICEF dan mitranya bekerja sama dalam memberikan penyelamatan nyawa yang ditimbulkan akibat dari adanya sisa-sisa ranjau atau persenjataan yang berbahaya bagi anakanak. Menanggapi penyebaran Covid-19 yang sedang berlangsung, UNICEF bersama dengan mitranya mengeksplorasi alternatif untuk upaya pembelajaran tatap muka sebagai bentuk perlindungan terhadap pendidikan anak-anak. Tidak lupa juga UNICEF tetap memberikan dukungan psikososial untuk 434.136 orang, termasuk 283.120 anak di 11 provinsi. Sehubungan dengan keamanan untuk anak-anak, UNICEF memberikan layanan 
ruang ramah anak atau Child Friendly Space. Layanan ini untuk membantu anak-anak mengatasi dampak jangka panjang akibat kekerasan yang mereka alami. Selain itu melalui program manajemen kasus, UNICEF memfasilitasi akses ke layanan kesehatan untuk anak-anak yang paling rentan dengan pengawasan pengasuh anak, dan dukungan psychosocial oleh para pelaku perlindungan anak mencapai 11.714 anak (UNICEF, 2020h). Sehubungan dengan keamanan anak pada kondisi konflik senjata yang terjadi, anak-anak diberikan pendidikan melalui pendidikan risiko ranjau atau MRE yang disediakan oleh UNICEF bekerja sama dengan pemerintah dan mitranya disampaikan di sekolah dan ruang ramah anak, serta melalui kampanye (UNICEF, 2019).

UNICEF dan mitranya pada tahun 2020 berupaya untuk dapat menjangkau 3.239 orang di Al-Jawf Yaman, dengan pencegahan Covid-19. UNICEF dalam hal ini juga melanjutkan advokasinya dalam upaya otoritas reunifikasi untuk anak-anak dan pusat remaja dengan keluarga mereka. Hal ini dilakukan sebagai upaya untuk mengurangi risiko infeksi akibat Covid-19 (UNICEF, 2020d). UNICEF dalam melindungi populasi yang terdampak juga akan memberikan fasilitas rehabilitasi untuk sekolah yang rusak, membangun ruang belajar sementara, serta menyediakan peralatan belajar dan mendukung pemberian insentif untuk mendukung staf dan guru pengajar. Selain itu satgas pemantauan dan pelaporan akan melibatkan pihak yang berkonflik sebagai upaya pencegahan dan menghentikan pelanggaran berat pada hak-hak anak. Untuk mendukung perlindungan menyeluruh bagi anak-anak terdampak konflik, serta mengingat disparitas gender yang semakin lebar dan kurangnya akses yang sama bagi perempuan dan laki-laki pada akses layanan dasar, maka UNICEF menjalankan perlindungan berbasis gender dan memberikan pelatihan kepada mitranya tentang pencegahan eksploitasi seksual dan penyalahgunaan hak anak.

Penutupan sekolah dan penangguhan pertemuan publik yang dilakukan sebagai upaya pencegahan penyebaran Covid-19 telah menghambat keberlangsungan pelaksanaan pendidikan risiko ranjau MRE dan dukungan psikososial yang sangat penting untuk anakanak terdampak. Oleh karena itu pada Juli 2020, UNICEF tetap menjalankan aksinya dengan memberikan perlindungan psikososial kepada 2.341 orang, termasuk 2.160 anak-anak di dalamnya (UNICEF, 2020e). Pemberian bantuan perlindungan psikososial tersebut dilaksanakan untuk anak-anak yang berada di wilayah Amran dan Aden, melalui jaringan ruang ramah anak untuk membantu mereka mengatasi jangka panjang keterpaparan terhadap kekerasan. Dalam mendukung pencapaian program perlindungan UNICEF, organisasi Save the Children di Yaman berupaya untuk menyediakan MHPSS sebagai bentuk dukungan untuk anak-anak yang terkena dampak konflik (Semmache, 2020). Dukungan ini diberikan melalui implementasi dukungan psikososial berbasis individu dan kelompok yang diberikan melalui: layanan ruang ramah anak sebagai tempat untuk anak-anak dapat bermain, berinteraksi, dan mengembangkan keterampilan kognitif mereka.

Program HEART penyembuhan dan pendidikan melalui seni membantu anak-anak di Yaman untuk berbagi perasaan dan pengalaman mereka melalui seni. Program pelatihan pertolongan pertama pada psikologis untuk anak, program ini diwujudkan melalui pengembangan alat oleh Save the Children untuk membantu para staf dan guru dalam mereduksi trauma pada anak-anak dan melalui layanan memperkuat perlindungan anak Save the Children juga mewujudkannya melalui peningkatan kesadaran tentang hak anak dengan 
dukungan pelatihan, pendampingan, dan dukungan teknis (Semmache, 2020). Dengan dukungan penuh melalui program manajemen kasus, UNICEF terus memberikan dukungannya dengan menyediakan layanan perlindungan anak yang penting bagi 274 anak dengan di dalamnya 136 anak perempuan dan 138 anak laki-laki (UNICEF, 2020e).

\section{Peran UNICEF dalam Education}

Di Uni Eropa terdapat waste hierarchy dalam penanganan sampah, yakni pencegahan (prevention), daur ulang dan penggunaan ulang (recycle and reuse), dan meningkatkan pembuangan akhir dan pengawasan (improving final disposal and monitoring). Sampah yang tidak bisa didaur ulang harus dimusnahkan dengan aman dan penggunaan tempat pembuangan akhir menjadi pilihan paling terakhir dalam penanganan sampah (Eurostat, 2019). Salah satu upaya yang dilakukan Uni Eropa dalam menangani permasalahan sampah adalah melakukan perdagangan sampah (waste trade) dengan negara-negara lain di Asia, termasuk Indonesia. Ekspor sampah dapat menguntungkan kedua pihak. Di satu sisi, Uni Eropa dapat mengurangi jumlah sampah yang ada di Uni Eropa. Di sisi lain, Indonesia bisa mendapatkan bahan baku yang dibutuhkan untuk keperluan industri. Persamaan antara kesepakatan perdagangan sampah ini adalah plastik merupakan material yang dilarang untuk dikirim ke negara tujuan.

\section{Peran UNICEF dalam Sanitasi (WASH)}

Infrastruktur dan sistem kesehatan Yaman telah melemah secara signifikan akibat terjadinya konflik selama lima tahun. Konflik yang terjadi telah menyebabkan kurangnya layanan dasar, pengungsian, dan kepadatan penduduk di pusat kota, sehingga layanan dasar yang tersedia semakin memburuk akibat pandemi Covid-19. Selain itu tingkat kemiskinan yang tinggi juga membuat keadaan semakin sulit untuk menerapkan langkah perlindungan bagi populasi terdampak. Lebih dari sepertiga dari 3,6 juta orang mengungsi yang tinggal di pemukiman spontan yang mana terdapat 50\% tidak memiliki layanan WASH yang memadai (Yemen WASH Desk Review, 2020). Penyediaan akses layanan WASH dilaksanakan oleh UNICEF dan WHO yang bertujuan untuk mempertahankan operasionalisasi sistem pasokan dan instalasi air. Hal ini dilakukan untuk memperkuat lembaga air setempat untuk dapat memastikan keberlanjutan penyediaan layanan promosi air, sanitasi, dan kebersihan serta mendukung pencegahan dan kesiapsiagaan untuk masa depan atau wabah penyakit. UNICEF bersama dengan WHO kemudian menggandeng World Bank dalam membentuk program The Yemen Emergency Health and Nutrition Project (EHNP) dan telah didanai sebesar US\$683 juta (World Bank, 2019). Program tersebut telah menghasilkan beberapa pencapaian terkait akses layanan dasar kebersihan dan kesehatan, yaitu: 1) terdapat 3.550 fasilitas kesehatan yang menerima biaya operasi, dan perlengkapan kebutuhan dasar, 2) tersedia 15.000 tenaga kesehatan terlatih, 3) 3,7 perempuan dan anak telah menerima layanan gizi, 4) sekitar 700.000 anak-anak berhasil diobati dari bahaya kolera dan berhasil menurunkan angka kematian, 5) tercapai sebanyak 6,9 juta anak mendapat layanan imunisasi, dan yang terakhir 6) sebanyak 630.583 wanita telah menerima perawatan prenatal dan kelahiran ditangani oleh tenaga kesehatan (World Bank, 2019). 
Kluster WASH akan memprioritaskan layanan penting dan telah disesuaikan untuk upaya pencegahan Covid-19 (WASH Cluster, 2020). UNICEF mengoperasikan dan menyediakan pemeliharaan sistem pasokan air bersih di kota-koa besar maupun daerah pedesaan terdampak konflik atau bencana. Sehubungan dengan ketersediaan air bersih UNICEF juga menyediakan bahan bakar, listrik, hingga disinfektan untuk klorinasi air. Pemberian bantuan pada layanan WASH juga dibarengi dengan pelaksanaan pemantauan kualitas air di rumah tangga dan dilakukan oleh otoritas sumber daya air nasional. Bantuan pada layanan WASH di Yaman, pada tahun 2019 telah membantu hampir 7,2 juta orangorang terdampak termasuk 3,2 juta anak-anak mendapatkan layanan air minum bersih dari dukungan UNICEF dan mitranya (UNICEF, 2019).

Secara total sebanyak 16,1 juta orang membutuhkan bantuan WASH di Yaman pada tahun 2020. Akses pada sumber air yang aman, bersih, dan terdekat tetap menjadi salah satu kebutuhan tertinggi di Yaman saat ini. Dari 66 kabupaten terdapat 49 di antaranya sangat membutuhkan akses yang lebih baik pada layanan WASH (Yemen WASH Desk Review, 2020). Selain itu kurangnya akses pada perbaikan sanitasi juga menimbulkan dampak yang cukup serius untuk perempuan dan anak-anak, hal ini akan berpotensi pada timbulnya masalah kekerasan berbasis gender atau pelecehan dan bahaya saat melakukan praktik buang air besar secara sembarangan yang dapat menyebabkan kebersihan dilingkungan sekitar akan semakin buruk. Dengan adanya pandemi Covid-19 yang terjadi maka kebersihan yang memadai merupakan salah satu kebutuhan tertinggi. Dari 58 kabupaten terdapat 44 kabupaten yang dinilai sangat membutuhkan fasilitas alat kebersihan seperti sabun untuk mencuci tangan (Yemen WASH Desk Review, 2020). Dengan memperhatikan kesehatan dan kebersihan di saat pandemi, maka kebutuhan akan mencuci tangan dengan sabun adalah langkah yang paling tepat untuk pencegahan utama penyakit menular seperti kolera dan Covid-19.

Munculnya wabah pandemi Covid-19 menyebabkan penurunan dana darurat yang signifikan untuk intervensi bantuan masyarakat. Oleh karena itu hal ini memberikan dampak pula terhadap menurunnya pencapaian lingkungan tempat masyarakat tinggal dari ketersediaan sanitasi yang layak, dan dilengkapi dengan promosi kebersihan termasuk kegiatan kampanye pengelolaan limbah padat. Pada tahun 2020 program layanan WASH UNICEF bersama dengan 77 mitranya dapat mencapai 91\% dari keseluruhan target layanan WASH. Hasil tersebut dapat mencapai 11.408 .471 orang mendapatkan beberapa bentuk layanan WASH di 304 kabupaten di 21 provinsi di Yaman. Layanan WASH bersama dengan mitranya juga berkontribusi dalam memberikan praktik kebersihan rumah tangga dengan mendistribusikan 92.000 alat kebersihan dan 22.124 kit pencegahan Covid-19 (UNICEF, 2020f). UNICEF sebagai organisasi internasional yang menjalankan perannya sebagai aid provider atau penyedia bantuan, dalam kesempatannya menanggulangi kekerasan anak di Yaman dengan memberikan bantuan kemanusiaan atau bumanitarian assistance yang distribusikan untuk anak-anak di Yaman sebagai yang terdampak konflik. UNICEF juga telah menjalankan perannya sesuai dengan tujuan dan fungsinya sebagai organisasi internasional dan sesuai dengan mandat PBB. UNICEF dalam hal ini mengalokasikan bantuannya dengan membentuk program bantuan di 5 bidang yaitu, Child Protection, Education, Sanitation, Nutrition, dan Health. Melalui pemberian bantuan pada 5 bidang tersebut diberikan melalui bantuan 
yang berbentuk material assistance atau sumber daya guna memenuhi kebutuhan dasar dan technical assistance yang diberikan melalui perekrutan relawan dari berbagai bidang. Hal ini bertujuan agar bantuan yang diberikan dapat tercapai dengan efektif dan efisien untuk anakanak di Yaman.

\section{KESIMPULAN}

Bantuan Humanitarian Assistance yang diberikan oleh UNICEF dalam menangani kasus kekerasan anak di Yaman pada masa pandemi Covid-19 telah sesuai dengan peranan organisasi internasional yang disampaikan oleh Kelly Kate Pease, Clive Archer dan John W. McArthur. Misalnya dalam penanganan Covid-19 di Yaman, UNICEF sedini mungkin telah memberikan rancangan untuk menangani pandemi tersebut serta memberikan bantuan berupa APD ke berbagai wilayah di Yaman. Tidak hanya itu dalam permasalahan penanganan kasus Kolera UNICEF melibatkan berbagai tim kesehatan yang telah dilatih untuk memberikan edukasi terhadap penularan penyakit Kolera serta cara mencegah dengan membersihkan dan memberikan air bersih.

Program-program yang telah dilakukan oleh UNICEF, tampak bahwa organisasi ini memiliki peran dan kontribusi dalam menangani kekerasan anak di masa pandemi Covid-19 di Yaman. Selain mengadakan program-program bantuan UNICEF juga mengadakan advokasi kepada masyarakat untuk menjaga kebersihan dan menjaga jarak agar terhindar dari penyebaran Covid-19. Hal ini dilakukan melihat keadaan fasilitas kesehatan di Yaman yang mengalami banyak kerusakan akibat konflik yang terjadi. Rehabilitasi anak yang dilakukan UNICEF juga sangat berperan penting sebab Yaman dalam 2 tahun terakhir banyak mengalami bencana alam seperti banjir yang mengakibatkan banyak fasilitas rusak serta meninggalnya masyarakat di sana. Program-program yang dilakukan oleh UNICEF sangat efektif dalam menangani kekerasan anak di Yaman pada masa pandemi Covid-19.

\section{DAFTAR PUSTAKA}

Aladokter. (2019). Kolera. Retrieved from Aladokter website: https://https//www.alodokter.com/kolera

Anonim. (2020). Apa yang dimaksud dengan pandemi? Retrieved from Covid19.go.id website: https://covid19.go.id

Archer, C. (2001). International Organization (3rd ed.). London: Routledge.

Australian Government. (2020). Emergency Relief. : Australian Goverment Department of Social Service.

BBC. (2020). Lima alasan mengapa yaman jadi tempat paling parah terdampak covid 19. Retrieved from BBC website: https://www.bbc.com/indonesia/dunia-53160746

Efendi, A. (2020). Yaman di Tengah Kepungan Corona, Kolera dan Krisis Kemanusiaan. Retrieved from Tirto.id website: https:/ / tirto.id/yaman-di-tengah-kepungan-coronakolera-dan-krisis-kemanusiaan-fUnZ

Eurostat. (2019). Waste Statistics. Retrieved from Eurostat website: https://ec.europa.eu/eurostat/statisticsexplained/index.php/Waste_statistics\#Total_waste_generation

Frihandy, R. (2014). Peranan United Nations International Children's Emergency Fund (UNICEF) dalam Menanggulangi Kelaparan dan Kekerasan pada Anak-anak di Yaman Tabun 2011-2013. 
Hospita, M. E. (2020). PBB: Bantuan medis terhambat karena penutupan bandara Yaman. Retrieved from Anadolu Agency website: https://www.aa.com.tr/id/regional/pbbbantuan-medis-terhambat-karena-penutupan-bandara-yaman/1979894

Kementerian Kesehatan Republik Indonesia. (2021). Situasi Terkini Perkembangan Coronavirus Disease (COVID-19) 22 April 2021. Retrieved from Kemenkes website: https://covid19.kemkes.go.id/situasi-infeksi-emerging/situasi-terkini-perkembangancoronavirus-disease-covid-19-22-april-2021

Lawrence, J. A., Dodds, A. E., Kaplan, I., \& Tucci, M. M. (2019). The Rights of Refugee Children and the UN Convention on the Rights of the Child.

McArthur, J. A., \& Conway, K. B. (2012). Exploring the relationship between studentinstructor interaction on Twitter and student perceptions of teacher behaviors. International Journal of Teaching and Learning in Higher Education.

Oktadewi, N., \& Khairiyah. (2018). PERANAN UNICEF DALAM MENANGANI CHILD TRAFFICKING DI INDONESIA.

Oxfam International. (2020). Rainy season threatens huge cholera spike in Yemen as conflict hampers efforts to address forgotten crisis. Retrieved from Oxfam website: https://www.oxfam.org/en/press-releases/rainy-season-threatens-huge-choleraspike-yemen-conflict-hampers-efforts-address

Pane, A. N. (2020). UNICEF Distribusikan 2 Miliar Dosis Vaksin Corona ke Negara Miskin Pada 2021.

Pease, K.-K. S. (2000). International Organization: Perspetives on Governance in the Twenty-First Century. Taylor \& Francis.

Perwita, A., \& Yani, Y. (2005). Pengantar Ilmu Hubungan Internasional. Bandung: PT. Remaja Rosdakarya.

Rasdiyanah, T. (2017). Konflik Israel-Palestina dan Pengarubnya terhadap Hubungan Diplomasi (Telaab Hukum Islam dan Pendekatan dalam Hubungan Internasional).

Rokom. (2017). Ingin Sehat? Mulailah Perhatikan Mikronutrien Tubuh. Retrieved from Sehat Negeriku Kemkes website: https://sehatnegeriku.kemkes.go.id/baca/rilismedia/20171031/1623580/ingin-sehat-mulailah-perhatikan-mikronutrien-tubuh/

Rosenau, J. N., Singer, J. D., \& Small, M. (1969). International Politics and Foreign Policy. New York: Free Press.

Semmache, Y. (2020). Five Years of Fear and Loss.

SOSCN. (1948). The Universal Declaration of Human Rights. Retrieved from https://soscn.org/UNCRC

Spieker, H. (2011). The right to give and receive humanitarian assistance. In International law and bumanitarian assistance. Berlin: Springer.

UNICEF. (1989). Konvensi Hak Anak: Versi anak anak. Retrieved from https://www.unicef.org/: https://www.unicef.org/indonesia/id/konvensi-hak-anakversi-anak-anak

UNICEF. (2019). Yemen Humanitarian Situation Report Desember 2019. Retrieved from www.unicef.org: https://www.unicef.org/media/77606/file/Yemen-SitRep-YearEnd-2019.pdf

UNICEF. (2020a). Humanitarian Action for Children. Retrieved from UNICEF website: https://reliefweb.int/sites/reliefweb.int/files/resources/2020-HAC-Yemen.pdf

UNICEF. (2020b). Over 5 million children face threat of Cholera and acute water diarrhea in the midst of COVID-19 as Yemen gets heavy rains. Retrieved from UNICEF website: https://www.unicef.org/press-releases/over-5-million-children-face-threatcholera-and-acute-water-diarrhea-midst-covid-19

UNICEF. (2020c). UNICEF airlifts COVID-19 testing kits to Yemen to boost response as 
cases soar. Retrieved from UNICEF website: https://www.unicef.org/pressreleases/unicef-airlifts-covid-19-testing-kits-yemen-boost-response-cases-soar

UNICEF. (2020d). Yemen Country Office Humanitarian Situation Report. Retrieved from https://reliefweb.int/sites/reliefweb.int/ files/resources/UNICEF Yemen Humanitarian Situation Report - For 1-31 July 2020.pdf

UNICEF. (2020e). Yemen Country Office Humanitarian Situation Report. Retrieved from UNICEF website: https://www.unicef.org/media/77581/ file/Yemen-SitRep-May2020.pdf

UNICEF. (2020f). Yemen Humanitarian Situation Report Desember 2020. Retrieved from https://www.unicef.org/media/93126/file/Yemen_Humanitarian_Situation_Report $\% 2$ C_End_of_Year_2020.pdf

UNICEF. (2020g). Yemen situation reports April 2020.

UNICEF. (2020h). Yemeni children face deadly hunger and aid shortages as COVID-19 pandemic spreads. Retrieved from UNICEF website: https://www.unicef.org/mena/press-releases/yemeni-children-face-deadly-hungerand-aid-shortages-covid-19-pandemic-spreads

WASH Cluster. (2020). Humanitarian Response. Retrieved from Humanitarian Response website: https://www.humanitarianresponse.info/en/operations/yemen/watersanitation-hygiene

Williams, V. C. (2006). Assuming Identities, Enhancing Understanding: Applying Active Learning Principles to Research Projects. Journal of Political Science Education, 2(2), $171-$ 186.

Wirawan, M. K. (2020). 5 Alasan Yaman jadi Negara Paling Terdampak Covid-19.

Retrieved from Kompas website:

https://www.kompas.com/global/read/2020/06/28/181035170/5-alasan-yamanjadi-negara-paling-terdampak-covid-19?page $=$ all

World Bank. (2019). Yemen Emergency Health and Nutrition Project. Retrieved from World Bank website:

https://www.worldbank.org/en/news/factsheet/2019/05/14/yemen-emergencyhealth-and-nutrition-project

Yemen WASH Desk Review. (2020). Secondary Desk Review on WASH Assessments in Yemen. 